\title{
THEORY AND ARGUMENT IN BIBLICAL CRITICISM*
}

\author{
$b y$ \\ EDWARD L. GREENSTEIN \\ The Jewish Theological Seminary of America, New York, NY 10027
}

"It is the viewpoint that creates the object." (de Saussure, 1966, p. 8)

Israeli archaeologist Gabriel Barkay has recently published a preliminary report and reading of Hebrew inscriptions incised on two thin silver strips (Barkay, 1986, esp. pp. 29-31). Each has been identified as a version of the so-called priestly benediction that appears in the Masoretic Text in Num 6:24-26. The larger text is said to contain traces of the three benedictions that we read in the MT. Contrary to what an innocent reader might suppose from any of a number of newspaper accounts of the discovery and deciphering of the texts, the paleographer, Ada Yardeni, did not identify the famous passage by simply reading the ancient Hebrew characters. She had, at first, considerable difficulty in distinguishing the Hebrew letters from other scratches in the silver. She could, however, make out three instances of the tetragrammaton, $Y H W H$. She proceeded to identify, decipher, and read additional letters and words only after a friend had suggested that, in view of the three occurrences of $Y H W H$, the text might correspond to the threefold priestly benediction (Rabinovich, 1986, p. 12). The delicately engraved

* An earlier version of this essay was delivered at the World Congress of Jewish Studies, Jerusalem, 1985, and printed as "The Role of Theory in Biblical Criticism" in Proceedings of the Ninth World Congress of Jewish Studies (Jerusalem, 1986), Division A, pp. 167-74. Thanks to the World Union of Jewish Studies to incorporate that essay into the present one. Thanks, too, to the Abbell Research Fund of the Jewish Theological Seminary of America for supporting part of the preparation of this essay. Although I have changed my position very little, I have been stimulated to rethink aspects of my original presentation through discussions and/or correspondence with Adele Berlin, Aaron Demsky, Yehoshua Gitay, Avi Hurvitz, Sarah Japhet, Jacob Milgrom, Yochanan Muffs, Michael OConnor, Uriel Simon, and Jeremiah Unterman. I am also indebted to conversations with Stanley Fish prior to composing the first version of the essay. Only I am responsible for what I have written. 
letters were found to be meaningful only after the paleographer had a prior hypothesis about what the text might contain. Even more to the point: once Yardeni had read three benedictions on the larger silver strip, she realized that one of the instances of $Y H W H$ that she had earlier noticed was not part of the three benedictions at all. It belonged to another part of the text. In other words, based on partially incorrect data, she tested a hypothesis that proved correct and, as a result, proved that some of the initial data was wrong. What should be clear from this particular account is that, as philosophers of science and others have long maintained, all observation, be it scientific or of the everyday variety, begins with a theory (cf. Pepper, 1948; Polanyi, 1969; Kuhn, 1970; Feyerabend, 1978; Popper, 1979; Fish, 1980). 'Our very observations, and not only our interpretations, are necessarily shaped by whatever presuppositions, hypotheses, and bodies of knowledge we possess. Our theories guide our selection of evidence, and even our construction of evidence.

In the case of Yardeni's reading of the silver engraving, the paleographer brought, we must imagine, a large number of theories or theoretical frameworks, within which she examined the inscription. She no doubt made assumptions about how to position the text for reading; about what script the text was written in; about the language of the writing; and, most strikingly, about what the letters might mean. We make assumptions in our work routinely, so much so that we tend to take them for granted. Let us consider a simple illustration.

No one, so far as I know, doubts that a number of chapters of biblical verse conform to the pattern of an alphabetic acrostic (e.g., Pss 34, 111, $112,119,145$; Prov $31: 10-3 \mathrm{I}$; Lam 1-4; and with varying degrees of irregularity Ps 9-10, 25, 37). Each line or couplet begins with a succeeding letter of the alphabet. Everyone, I suppose, will agree that the alphabetic acrostic was a convention of ancient Israelite verse. That conclusion, with which I concur, rests upon a number of assumptions that can be posited axiomatically but cannot be proved or deduced from unassumed premises. To begin, one discovers the acrostic in the first

1. Although these and other discussants of theory disagree on many issues, such as the role of evidence in supporting a theory and the necessity of conducting tests for possible falsification of a theory, they agree on this. For summary discussion, see Barbour (1974). Barbour pays proper attention to types of models (esp. pp. 29-33) and to criteria for evaluating competing models or theories (esp. pp. 112-18), but while these are two issues that deserve special attention in a wider discussion of the role of theory in biblical criticism, I confine myself to arguing the more limited, prior claim that biblical studies unavoidably draws on nondemonstrable presuppositions and beliefs, even at the stage of defining the evidence. On this point, cf. Barbour's summary discussion on pp. 94-98. 
place only after one already has a prior concept of what an acrostic is. We match our concept of the acrostic with the pattern that we find in the biblical text. But in order to find that pattern one must first apply some theory for defining the lines of verse and divide the text into lines. One must then decide that the initial letter of every line or every other line belongs not to a random pattern but to a meaningful design. In the case of the alphabetic acrostic, the meaningful design is the Hebrew alphabet. Without knowing what an acrostic is, one could not discover the alphabet in the pattern; and without knowing the Hebrew alphabet one could not have found the acrostic pattern in the text. The two identifications are twin components of a single construct.

To claim that the alphabetic acrostic was a convention of Israelite verse demands that we make additional assumptions: that the ancient bard intended to pattern his lines according to an alphabetic acrostic, and, further, that the Israelites had an alphabet. Since we are not "empirical" observers of the biblical world and its historical setting, even the existence of an ancient Hebrew alphabet rests on theory. ${ }^{2}$ To prove that the Hebrews had an alphabet we cannot use the very acrostics we are discussing to document the existence of the alphabet. This would be arguing in an obvious circle. One can, of course, adduce the 'Izbet Sartia inscription, part of which more or less corresponds to our idea of the Hebrew alphabet; and one can go farther afield and identify cognate alphabets in Ugaritic and ancient Aramaic and Ammonite epigraphs (see Demsky, 1977 and Lemaire, 1985, p. 39). But without a prior notion of what an alphabet looks like one could not have found alphabets in these extra-biblical texts either. To use our identification of the alphabet in one place to prove its existence in another is merely, borrowing a phrase from Nabokov's Lolita "like a conjurer explaining one trick by performing another."

Rather, in identifying the alphabet in extra-biblical texts and in discovering alphabetic acrostics in the Bible we follow a certain set of assumptions or beliefs - our theory of the alphabet and its use. The theory entails the assumptions that an ancient Israelite verse-maker and his audience knew the alphabet and that the use of the alphabet in an acrostic was a convention of ancient Hebrew verse. On the basis of this set of premises, we make deductions concerning the structure of various biblical psalms and elegies.

2. As I shall claim below, even had we lived in biblical times, our observations would remain hypothetical. The term "empirical" is used to deny the necessary "subjective" features of all observation. 
My intention is not to cast doubt on the reality of alphabetic acrostics in the Bible. It is rather to avow that whenever we make literary or any other kind of observations on the Bible, or on any other texts, we have no choice but to use the models with which we are familiar to identify and classify that which we observe (cf., e.g., Kugel, 1981, p. 302; Magonet, 1986, p. 91). We find parallelism, chiasm, meter, even metaphor in biblical verse only after we have a theory of what those literary forms are. The theory adopts or develops methods for identifying those forms.

One cannot simply "infer," as Alter suggests (1983, p. 118), the conventions of the literature "by a careful inspection of the texts." ${ }^{3}$ Alter himself has implicitly acknowledged this point elsewhere (1985, pp. 2056), where he admits that a "scholar from another planet" without any training in Elizabethan poetry would fail to discover the most evident patterns in Shakespeare's sonnets. One cannot in unmediated fashion "elicit ... the innate conventions and literary formations of a piece of ancient literature" (Greenberg, 1983, p. 21). It is impossible, as Fish (1980) and Mitchell (1985) and others have contended at length, to "curb all temptations to impose [our] antecedent judgments on the text" (Greenberg, 1983, p. 21). The process of perception, even in psychophysics (e.g., Hochberg, 1978, p. 88), is not merely one of receiving and storing stimuli. It is always an interpretive process, an active, though largely automatic, implementation of our prior models, presuppositions, and analytic strategies. It is use $1 \mathrm{l}$ to become aware of our assumptions so that we may subject them to criticism and reconsider our reliance on them (cf. Greenstein, 1985). But even when we do not notice them, they are there.

The most exact science begins with deductions from hypothetical foundations. Consider this description by Albert Einstein (1950, p. 96):

Physics constitutes a logical system of thought which is in a state of evolution, and whose basis cannot be obtained through distillation by any inductive method from the experiences lived through, but which can only be attained by free invention.

As Einstein had already characterized the project of physics in 1918 (in Pirsig, 1975, p. 99): "The supreme task . . is to arrive at those elementary laws from which the cosmos can be built up by pure deduction." The root of the laws lies in the model in the thinker's imagination: 
Man tries to make for himself in the fashion that suits him best a simplified and intelligible picture of the world. He then tries to some extent to substitute this cosmos of his for the world of experience, and thus to overcome it. ${ }^{4}$

What has been acknowledged for physics applies as well to the social sciences and humanities (cf. Scholes and Kellogg, 1966, pp, 276, 278; Chomsky, 1972; Culler, 1975) and has been recognized by some for the specific field of biblical studies (cf., e.g., Polzin, 1977; Gibson, 1981; Barton, 1984).

The best known instance of applying a model in biblical studies involves source criticism in general and the Documentary Hypothesis in particular. Tsevat (1975) has challenged biblical critics to state their underlying assumptions, their "first principles," and subject them to models that are familiar to us from other sources. Tigay (1975, 1982, 1985; cf. Kaufman, 1982) has suggested that his own and others' source critical analyses of other ancient Near Eastern texts might serve as an appropriate model for reconstructing the composition of the Torah. ${ }^{5}$ This is a perfectly valid proposal. What is mistaken is the concomitant claim that such analyses are somehow "empirical." An empirical observation claims to examine directly the actual historical composition of the texts in question. On this Steiner (1975, p. 137) has stated the counterclaim succinctly: "To all past events, as to all present intake, the observer brings a specific mental set." The so-called "empirical" observation of concrete "evidence" is mediated by theory just as all observation is. What Tigay and others ${ }^{6}$ produce are theories concerning the historical relationships of ancient Near Eastern texts. They, too, are informed by a number of presupposed principles. For example, Tigay

4. Husserl (1962), too, has contended that physics applies its own principles of logic in order to create a "hypothetical substructure" of "thing realities" (p. 147).

5. Tigay's model of composition of the Gilgamesh Epic actually resembles the model of Van Seters (see below) more than the classical Documentary Hypothesis; of. Rainey (1978).

6. In addition to the contributors to Tigay (1985), of. also Berlin (1983, esp. pp. 129ff.). Somewhat analogously, Fishbane (1985) seeks to distinguish different types of ancient scribal explication of the biblical text on the basis of whether "formulaic indicators" of such explication are evident. Such indicators, says Fishbane (p. 56), "permit a relatively objective identification of the scribal comments involved." However, Fishbane seems to overlook that it is only through his own, or someone eise's, exegesis that certain words or phrases in the Hebrew are taken to be "formulaic indicators" of "scribal comments." There is nothing even "relatively objective" about such exegesis. Although Fishbane may himself feel more sanguine about his determination of explicit scribal annotations than about his 
assumes that documents that are found to have affinities to earlier documents are related through some history of written composition. His evidence for relations in writing can also be explained by assuming that the written texts reflect different orally performed versions of the text at hand (see, e.g., Tigay, 1982, pp. 58-59, 61ff., 82ff., and passim). Tigay dismisses this alternative by asserting that he distrusts the hypothesis of oral prototypes (1982, pp. 102-3). Tigay may be correct, but we can never know that because, by definition, oral performances, until recently, have gone unrecorded. One may not make a virtue out of a necessity and bar unattested and unattestable material from our hypotheses. In more extreme fashion Van Seters virtually disqualifies all "prior versions" of a biblical text from a hypothesis concerning the historical development of that text (1975, pp. 155-56). Precisely because no one has direct access to the history of ancient literature, one will always remain in the position of imagining, or hypothesizing, the history of the text.

This, in fact, is always the case with history. The history is not in the data but in the analysis. It is worth repeating here the well-known remarks of Carr (1961, p. 10): "The belief in a hard core of historical facts existing objectively and independently of the interpretation of the historian is a preposterous fallacy, but one which it is very hard to eradicate" (cf. Kurzweil, 1970, part 2). The role of a theoretical model behind the historian writing the story of ancient Israelite history has been cleverly illustrated by Sasson (1981) in his contrast of the American and German schools of modern biblical historiography. He argues, in a manner that is highly suggestive if not altogether convincing to me, that scholars have imagined - and reconstructed -the origins of the Israelite tribal union according to the way in which their own nations confederated. America was colonized by waves of immigrants who eventually formed a union of states, and so have W. F. Albright and John Bright, and others, conceived of the formation of ancient Israel. Germany was unified only through the later confederation of a number of originally autonomous local states-a model that has been translated by A. Alt and M. Noth to the early history of Israel. Indeed, the academic controversy concerning the emergence of Israel has turned more and more explicitly into a discussion of competing models (for a summary of

determination of implicit ones, both kinds of determinations are products of his own analysis. Indeed, without going into details here, I find some of his identifications of "unmarked" explications more convincing than some of his identifications of "formulaically indicated" ones. 
the models, see Gottwald, 1985, pp. 261-88). Rendtorff (1986, p. 22) puts it this way:

Each of the models is based on particular presuppositions which often seem more important in the discussion than the reconstruction itself, since they involve methodological, historical, and theological questions of principle, all at the same time.

It would therefore seem useful in academic discourse among scholars taking divergent theoretical stances to acknowledge the differences in first principles or beliefs that divide us before proceeding to examine the argumentation or logic of the other's positions. Greenberg (1983, p. 20) points out the axiomatic first steps of scholarship when he speaks of the "a prioris, an array of unproved (and unprovable) modern assumptions and conventions that confirm themselves through the results obtained by forcing them on the text...."Greenberg has in mind those biblicists who assume that the earlier and more original the material is, the simpler and more thematically uniform it is. By isolating small passages that display simplicity and inner coherence, such scholars believe that they are identifying the historically earlier units of a given text. Greenberg, however, refers to the assumptions of these critics as "prejudices," as though one could choose to be neutral and unprejudiced. But, as Rorty $(1982,1984)$ and others (notably Fish) have demonstrated, we all begin with beliefs or assumptions that guide us in our observations and analyses. Greenberg reveals his own premises in the following pages (1983, pp. 25-26): that the text at hand is to be taken as a whole; that one should "look ... for design and for integrating elements" in order to find patterns; and that discontinuities in the text constitute variations on the pattern rather than indications of disparate sources. This set of assumptions belongs to a coherent theory. It is not an argument of theory versus no theory, or subjectivity versus neutrality. It is an argument between a theory of multiple composition and a theory of single or homogeneous composition.?

One finds an analogous opposition of initial premises in the area of textual criticism (see further Tov, 1984/85). The position that regards textual emendation with suspicion has been clearly articulated by Gordis (1982, p. 198): "the given text is a datum and the emended, deleted or transposed text is a hypothesis." In fact the restructured text is hypothetical. The acceptance of the received text, based on whatever beliefs,

7. Cf. Barrick (1986), who, in his review of Greenberg (1983), observes that "Greenberg operates in an entirely different mode" from typical historical critics. 
is also hypothetical, though. One cannot know that the received text is more original, or "better" in any other way. Gordis employs the metaphor of the text as a body in need of medical repair (cf. his title: "Traumatic Surgery in Biblical Scholarship"). Surgery might be a last resort if the body could be mended by less "traumatic" means. But if a scholar judges that a text is dismembered, only surgery can bind the parts together into an organic whole. It is the initial assumption or hypothesis of the physician, as it is of the philologist, to decide whether one should work with the corpus as it stands or to rebuild the corpus into a unity.

Returning to the higher criticism of the Torah, the debate over the composition of the Pentateuch often represents itself as an argument about logic, methodology, and data. As I see it, however, the contest is often between theories or models of composition. Each theory, as Rendtorff has explained (1984, esp. p. 11), applies the methods of analysis or exegesis that serve its ends. As Carr has written of professional historians, "By and large, the historian will get the kind of facts he wants" $(1961$, p. 26). The analyst ascertains what facts are significant and in what manner to arrange them. This is not meant to disparage historiography; it is meant to describe the only way, under the best of circumstances, that any scientific, as well as humanistic, inquiry can operate. If the source critic assumes that every shift in style or topic conveys special significance, one will never discover diverse sources in the Torah. Applying the tools of source critical analysis, one will perforce disintegrate the text. Because the very tools that a critic uses will perform the task that the critic envisions at the outset, one cannot legitimately use the methods and conclusions of one theory in criticizing another. Each theory's methods select and interpret evidence in order to support or lend substance to the arguments that hold up the theory. One may prefer a house of bricks to a house of wood. But one should not fault the mason for using bricks and mortar instead of boards and nails.

When, for example, Segal attacked the Documentary Hypothesis, he was correct in describing the regnant source theory of his day as follows (1967, p. 2):

The principal assertions of the [Documentary Theory's] system, originally nothing more than pure suppositions, have now matured with age and with constant repetition into axiomatic truths, which control the thinking of scholars and direct their approach to biblical problems.

His remarks have been recently echoed by Rendtorff $(1984$, p. 2$)$ :

The documentary hypothesis was a dogma and every scholar who wanted to be accepted by the establishment of Old Testament scholarship had to 
submit to this theory in order to demonstrate that he was able to handle the established method.

What they describe happens in the growth of any discipline or science. Once a number of workers in the field become convinced of a hypothesis or model, they accept it as an axiom and proceed from there (see, e.g., Kuhn, 1970 and Feyerabend, 1978). They make deductions from their shared axioms. Segal opposed the Documentary Hypothesis and its source analytical procedures because they conflicted with his own model of a singly authored text with occasional supplements. Accordingly, he criticized source criticism for its method of "wrench[ing] . . passage[s] out of [their] context[s] . . and interpret[ing them] as independent of what precedes ... and what follows...." (Segal, 1967, p. 5).

Applying the tools of his own model of unitary composition, Segal performed often idiosyncratic exegesis so that the theory he espoused would seem impregnable. He interpreted Exod 3:13, mã šĕmô, for example, to mean not "What is his name?" but rather "What meaneth his name? What is its import and its significance?" (loc. cit.). In Segal's view, of course, the Hebrews would already have known the tetragrammaton, as it was used throughout Genesis. The common enough Hebrew phrase must, according to his approach, have a sense that differs from its ordinary one. His theory affects, or colors, his reading of Exodus. Because for Segal the Torah is "a continuous whole," the interpreter should "seek out the Theme which guides its successive events and the aim to which they are leading" (p. 22). He claimed that this approach to the text was the one the text itself called for because the text as we now have it is, and has been preserved as, a single piece. This circular argument cannot be accepted by anyone who would conceive of a model of composition other than that of single authorship. The reasoning of Segal resembles that of those, cited above, who discount the hypothesis of written sources or oral traditions because they do not exist (now). If one believes in a theory of composition that involves the positing of oral sources, one's beliefs cannot be shaken by pointing out that those sources do not exist anymore. An archaeologist does not confine himself to existing potsherds in diagramming an ancient jug. One imagines that a hypothetical jug possessed the missing pieces, the ones that may have been lost forever, in making one's reconstruction. The literary historian, as another hypothesis builder, must imagine the complete model of a text consisting of all the pieces that one believes once existed.

While many scholars are aware that we have conflicting models of the Torah's composition among us, few of us, in our public discussion of 
rival theories, act on that awareness. In order to illustrate my claim, and distinguish between differences in belief or model and differences in logic or argumentation, I shall draw on my reading of twelve professional reviews - many of them lengthy- of Van Seters' book, Abraham in History and Tradition, published in 1975. Van Seters challenged the Graf-Wellhausen Documentary Hypothesis as it was developed by Noth. According to that theory, as summarized, for example, in Freedman (1962), the written sources $J$ and $E$ adapted a common tradition, $G$, that was either oral or written. $J$ and $E$ were redacted into a single edition. Van Seters, on the other hand, following the lead of his teacher Winnett (1965) and anticipated by such nineteenth century scholars as Ewald (see de Pury, 1978, p. 604 with n. 39), described a different theory. Before proceeding to delineate that theory it will be useful to consider the reasons that Winnett and Van Seters sought an alternative to the modified Documentary Hypothesis. Few of Van Seters" reviewers considered this.

First, the scholarly consensus on the Graf-Wellhausen theory had been deteriorating persistently for decades. Second, Winnett and Van Seters felt that source analytical procedures fragmented what looked to them like "unified stories and episodes" (Van Seters, 1975, p. 127; cf. Winnett, 1965, pp. 6, 10). Third, the E source is notoriously difficult to document except in the so-called "doublets," stories that are told twice or more. Fourth, Winnett and Van Seters recognized that the hypothesis of a common source for $J$ and $E$, a Grundlage, and the assumption of a series of redactors were necessitated only by dint of the prior hypothesis of discrete written sources, J and E (Van Seters, 1975, pp. 125-29).

A fifth, and so far as I know unstated reason for the alternate theory, is simply that Winnett and Van Seters imagined a different possibility for explaining the Torah's composition. It is true that new theories are often advanced in response to a crisis: the old theory would not solve a nagging problem. It is also true, however, that new theories have frequently been introduced when most scholars were content with the old ones (cf., e.g., Kuhn, 1970). New theories need not emerge over the rubble of a shattered older theory. To insist that they do is to commit what Pepper (1948, p. 100) has called "the fallacy of clearing the ground." Nor need a new theory explain the presently known evidence better than the older theory. New theories will define new issues and may restructure the current data into different evidence altogether. Because, as I have argued above, theory informs observation, too, new theories will yield new evidence (cf. especially Feyerabend, 1978).

Van Seters' work interests us because he in fact shares most of the assumptions and methods of other historical critics (cf. Thompson, 
1978, p. 77). He marshals them toward a different conclusion, however. In our discussion of his work we shall focus not on his dating of the patriarchal narratives but on his, and Winnett's, model of how the Pentateuch was composed. Briefly put, this model views the text's composition not as a redaction of parallel documents but as an agglomeration of successive revisions. It sees a series of writers taking older documents and composing new material to supplement and rewrite those documents. Certain explicit presuppositions guide Van Seters' work. First, as I have noted above, is his disbelief in a background of oral traditions behind the written text (see now also Van Seters, 1983). Put positively, he places a premium on the written evidence at hand. Second, he asserts that the same writer would not write the same story twice. This, it should be remarked, is consistent with his first premise, as we ordinarily associate different versions of the same story with oral narration. Third, only gross discontinuities in the text betray signs of diverse sources (Van Seters, 1975, pp. 154-56). Now let us review what the critics have done with Van Seters.

In general, critics admired his work, even when dissenting from his conclusions. A number either neglected or paid little attention to his literary analysis (e.g., Clements, 1977; Rainey, 1978; Sarna, 1977), which is clearly the more significant, as well as the larger, part of his book (so Van Seters, 1978, p. 6). Some opposed Van Seters' theory because it rejected the oral background of the narratives that so many came to believe (e.g., McEvenue, 1977; Nicholson, 1979; de Pury, 1978; Sarna, 1977; van Selms, 1977). In and of itself, this is legitimate. But it is no criticism. The absence of oral tradition fits in perfectly with Van Seters' model, in which, for the most part, writers rewrite writers. ${ }^{8}$ Thompson $(1978$, p. 80), in what is otherwise the most sophisticated discussion of Van Seters, faults him for his "methodological tendentiousness." Every method is, in a sense, tendentious, though, as it drives toward a specific, foreseen goal. The type of argument and rhetoric that one uses in the service of a theory, as well as the evidence one adduces in support of the argument, would never have been exercised had they not sustained the theory. That is why, as Fish (1980, p. 68) says, "theories always work and they will always produce exactly the results they predict," and that is what Stein (1982, p. 80) explains by writing "A bed is always comfortable if it is made so."

8. Van Seters (1983, pp. 18ff.; 226-227.), however, criticizes the argument for an early oral epic behind the Pentateuchal narrative without ever answering the arguments adduced from verse fragments, taken to be excerpts from an earlier epic, within the present text. Aside from Cross (1973), see especially Cassuto (1975; first published in Hebrew in 1943). 
Some reviewers (e.g., Cazelles, 1978; McEvenue, 1977; de Pury, 1978) attacked Van Seters' literary analysis by applying different methods to his texts and by showing that the different methods yield results in line with an alternate theory. That is, however, as it must be. One cannot prove anything by criticizing one theory with the tools of another one, as I have said above; recall the analogy of the mason and the carpenter. Van Selms (1977), for example, agreed with Van Seters that the author of Genesis 21 knew the text of Genesis 16. In Van Seters' theory that is because the author of chapter 21 was rewriting chapter 16; in the reviewer's theory that is because the same author wrote both. Others, assuming the independence of an E source (e.g., McEvenue, 1977; cf. idem 1984) and the work of a redactor, performed variant interpretations of Van Seters' texts with the methods of the Documentary Hypothesis. Van Seters was well aware of source critical alternatives before he began.

Gen 21:8, for example, refers not to Isaac but to hayyeled, "the boy." Since "the boy" presupposes Isaac, Van Seters (1975, p. 196) contends that this verse must be an integral part of the preceding passage. A source critic could argue, in opposition, that when the passage containing verse 8 was joined to the preceding one, the redactor replaced "Isaac" with "the boy." Similarly, Hagar's expectation of inheritance rights in chapter 21 presupposes the situation at the beginning of chapter 16. For Van Seters (1975, p. 197), this proves that the author of chapter 21 depended on a preexisting chapter 16 . But one could counter that chapter 21 once contained similar information which was omitted in the process of redaction as an unnecessary duplication. All I am saying is that proponents of different theories will perform different analyses. One cannot further discussion by criticizing a theory through the conceptual framework and methods of another theory.

Nicholson $(1979$, p. 231$)$ has challenged Van Seters' model by asking why an author would write a different story in order to revise one he did not like. Why not simply replace the earlier story with a new one? One could ask the same thing of the hypothetical redactor. But raising the question-rather than imagining an answer-reflects the failure to realize that one is judging Van Seters by one's own methods. Winnett had a decade earlier provided an answer: the author customarily added new material to old while conserving the old. One may not believe that this is what happened; but it is perfectly plausible that it did. At bottom, debates over compositional history, as over all our other concerns, boil down to conflicts of presuppositions, first principles, beliefs.

Finally, some reviewers (e.g., Cazelles, 1978; Pardee, 1979; Roberts, 1977) dismissed Van Seters' reconstruction because it took account of 
Genesis alone, and only part of Genesis at that. They implied that such a theory might not be able to explain the composition of the entire Torah, or of at least the Tetrateuch. Again, such critics did not look beyond the Documentary Hypothesis to entertain the possibilities of another theory. The Documentary Theory begins with the assumption of large parallel sources, overlapping in their coverage of a long stretch of Israelite tradition. Adherents of this theory would naturally consider it essential to examine the whole before drawing any conclusions. But Van Seters' theory assumes a stratified model, adding layer to layer. It makes sense within this model to begin with a limited block of material, and the research of Rendtorff $(1977,1984)$ on later parts of the Torah can be invoked in support of the promise of Van Seters' theory. Source critics should remember, too, that the Documentary Hypothesis also started small.

We can further appreciate the role that our presuppositions play in our argumentation and rhetoric by examining, or deconstructing, the language that we use in our criticism. To take one example from the Van Seters literature, at least four reviewers contended with Van Seters by asserting that the evidence actually "points" in a different direction (Clements, 1977, p. 91; Rainey, 1978, p. 132; Roberts, 1977, p. 109; Sarna, 1977, p. 9). Van Seters has himself used this expression in his reply to criticism (1978, pp. 6-7). Using language that places the truth in the power of the evidence gives the impression that it is not we who rely on our own force of logic or persuasion but that some external, "objective" standard articulates the truth for us. "Pointing" evidence, of course, is actually a metaphor, a personification of the data that we have found, structured, and adduced. We interpret the evidence, and we point it. By acknowledging our role behind the evidence we become more aware of our principles and models, and of those of the other person.

To conclude, I return to the silver inscriptions with which we began. According to all reports, the larger text contains three benedictions, similar to those in Num 6:24-26. The shorter one presents two benedictions. The second one seems to contain the first half of the second blessing in the MT and the second half of the third. Barkay (1986, p. 30) reads it as follows: $y$ r $y h[w h]$ pnyw [l]yk w[ys]m $l k s[l] w m$ "May YHWH shine his face toward you, and may he grant you peace." Is this benediction a literary (intentional) conflation of the latter two blessings in the longer version? Barkay (p. 30) seems to think so, as he compares the benediction in Ps 67:2, which resembles parts of the first two blessings in Numbers 6 . It is also possible that the scribe skipped from the first half of the second blessing to the second half of the third, as the first half of each ends with the same phrase, pnyw \%yk "his face 
toward you." It would then be a case of homoioteleuton, one of the commonest of copyist errors. Which is more likely? There is no method that can dictate an answer. The method or approach (explain the text as it stands, or restore the text to its perfect form) depends upon our view of the inscription and how we imagine the scribe wrote it. Was he careless? Was he cramped by the short space? Was he underpaid? Was he interested in conveying a shorter text? Was he trying to be creative? We cannot know. We will take a stand, if we choose to do so, in accordance with other assumptions that we have made, or theories that we hold dear. Whether we see a whole text or a defective one involves a range of beliefs. To engage in our work as Biblicists means we must exercise our beliefs.

Does this mean that we cannot appeal to a standard, to a higher authority? Within the academic community, or any other, we share common assumptions with other people, conventions that enable us to communicate with each other (see Fish 1980). ${ }^{9}$ When the community to which we belong, or choose to belong, accepts a set of assumptions as "facts," we then take them for granted and build our arguments upon them (cf. Pepper 1948). In Biblical studies, we have been passing through a period in which many of the old "facts" have been challenged. One therefore may facilitate discussion and understanding by laying bare our assumptions and sorting out those of the arguments we criticize. We might then find that our arguments over method are fundamentally differences in assumptions or beliefs.

9. Fish's concept of interpretive communities has been widely criticized (see some of the essays in Mitchell, 1985, for example) and misinterpreted. Scholes (1984), pp. 129 65, misses Fish's point that it is a community-whichever community (since language and semiotic codes in general are never strictly solipsistic) - that creates the code for interpreting even so apparently factual a datum as a punctuation mark. Most critics misread Fish by failing to realize that he is describing how he thinks we read or interpret evidence rather than prescribing how we ought to do so. Further, when Fish asserts that we write what we read he means that the reader must take full responsibility for one's readings, which are not the unmediated product of what the text says but of what one makes of the text. In representing my sympathy with Fish's views I do not indicate here the more radical aspects of his position. I confine myself to the major themes of the essay: that theory precedes observation and that so much controversy in biblical studies boils down to differences over competing theories or fundamental beliefs. It is worth noting, too, that I would formulate much of my own writing on Bible differently were 1 to start over according to my current thinking. In general I nowadays speak more carefully of what I read than of what the text "says." Nevertheless, there is no harm in personifying, and of objectifying, "the text" so long as one is aware and makes others awate of what one is doing. 


\section{BIBLIOGRAPHY}

Alter, R. 1983. "How Convention Helps Us Read: The Case of the Bible's Annunciation Type-Scene." Prooftexts 3:115-30. 1985. The Art of Biblical Poetry. New York.

Barbour, I. 1974. Myths, Models, and Paradigms. New York.

Barkay, G. 1986. Ketef Hinnom: A Treasure Facing Jerusalem's Walls. Jerusalem.

Barrick, W. B. 1986. Review of Ezekiel 1-20 by M. Greenberg. Journal of Biblical Literature 105:142-44.

Barton, J. 1984. Reading the Old Testament. Philadelphia.

Berlin, A. 1983. Poetics and Interpretation of Biblical Narrative. Sheffield.

Carr, E. H. 1961. What Is History? New York.

Cassuto, U. 1975. "The Israelite Epic." Biblical and Oriental Studies. Tr. by I. Abrahams, Vol, 2:69-109. Jerusalem.

Cazelles, H. 1978. Review of Abraham in History and Tradition by J. Van Seters. Vetus Testamentum 28:241--55.

Chomsky, N. 1972. Problems of Knowledge and Freedom. New York.

Clements, R. E. 1977. Review of Abraham in History and Tradition by J. Van Seters. Journal of Semitic Studies 22:90-92.

Cody, A. 1976. Review of Abraham in History and Tradition by J. Van Seters. Catholic Biblical Quarterly 38:601-3.

Cross, F. M. 1973. Canaanite Myth and Hebrew Epic. Cambridge, MA. Culler, J. 1975. Structuralist Poetics. Ithaca.

Demsky, A. 1977. "A Proto-Canaanite Abecedary dating from the Period of the Judges and Its Implications for the History of the Alphabet." Tel Aviv 4:14-27.

Einstein, A. 1950. Out of My Later Years. New York.

Feyerabend, P. 1978. Against Method. London.

Fishbane, M. 1985. Biblical Interpretation in Ancient Israel. Oxford.

Fish, S. 1980. Is There a Text in This Class? Cambridge, MA.

Freedman, D. N. 1962. "Documents." In Interpreter's Dictionary of the Bible. Ed. G. A. Buttrick et al. Nashville.

Geller, S. A. 1984. "Some Pitfalls in the 'Literary Approach' to Biblical Narrative." Jewish Quarterly Review 74:408-15.

Gibson, A. 1981. Biblical Semantic Logic. New York.

Gordis, R. 1981. "Traumatic Surgery in Biblical Scholarship: A Note on Methodology." Journal of Jewish Studies 32:195-99.

Gottwald, N. K. 1985. The Hebrew Bible: A Socio-Literary Introduction. Philadelphia. 
Greenberg, M. 1983. Ezekiel 1-20. Anchor Bible \#22. Garden City.

Greenstein, E. L. 1985. Review of Biblical Semantic Logic by A. Gibson. Journal of the American Oriental Society 105:735-36.

Hochberg, J. E. 1978. Perception. 2nd ed. Englewood Cliffs.

Husserl, E. 1962 [1931]. Ideas: General Introduction to Pure Phenomenology. Tr. W. R. B. Gibson. New York.

Kaufman, S. A. 1982. "The Temple Scroll and Higher Criticism." Hebrew Union College Annual 53:29-43.

Kugel, J. L. 1981. The Idea of Biblical Poetry. New Haven.

Kuhn, T. S. 1970. The Structure of Scientific Revolutions. 2nd ed. Chicago.

Kurzweil, B. 1970. Běma’avaq 'al 'erkê hayyahadût. Jerusalem.

Lemaire, A. 1985. "Fragments from the Book of Balaam Found at Deir Alla." Biblical Archaeology Review 11/5:26-39.

Magonet, J. 1986. "The Structure of Isaiah 6." Proceedings of the Ninth World Congress of Jewish Studies. World Union of Jewish Studies, Jerusalem. Division A:91-97.

McEvenue, S. E. 1977. Review of Abraham in History and Tradition by J. Van Seters. Biblica 58:573-77.

1984. "The Elohist at Work." Zeitschrift für die alttestamentliche Wissenschaft 96:315-32.

Mitchell, W. J. T., ed, 1985. Against Theory: Literary Studies and the New Pragmatism. Chicago.

Nicholson, E. W. 1979. Review of Abraham in History and Tradition by J. Van Seters. Journal of Theological Studies 30:220-34.

Pardee, D. 1979. Review of Abraham in History and Tradition by J. Van Seters, Journal of Near Eastern Studies 38:146-48.

Pepper, S. C. 1948. World Hypotheses: A Study in Evidence. Berkeley.

Pirsig, R. M. 1975. Zen and the Art of Motorcycle Maintenance. New York.

Polanyi, M. 1969. Knowing and Being. Ed. M. Grene. Chicago.

Polzin, R. 1977. Biblical Structuralism. Missoula and Philadelphia.

Popper, K. R. 1979. Objective Knowledge. 2nd ed. Oxford.

Pury, A. de. 1978. Review of The Historicity of the Patriarchal Narratives by T. L. Thompson and Abraham in History and Tradition by J. Van Seters. Revue Biblique 85:589-618.

Rabinovich, A. 1986. "Word for Word." Jerusalem Post Magazine. July $18: 10-12$.

Rainey, A. F. 1978. Review of Abraham in History and Tradition by J. Van Seters. Israel Exploration Journal 28:131-32.

Rendtorff, R. 1977. Das überlieferungsgeschichtliche Problem das Pentateuch. Berlin. 
1984. "The Future of Pentateuchal Criticism." Henoch 6:1-14. 1986. The Old Testament: An Introduction. Philadelphia.

Roberts, J. J. M. 1977. Review of Abraham in History and Tradition by

J. Van Seters. Journal of Biblical Literature 96:109-13.

Rorty, R. 1982. Consequences of Pragmatism. Minneapolis. . 1984. "Deconstruction and Circumvention." Critical Inquiry 11:1:1-23.

Sarna, N. M. 1977. "Abraham in History." Biblical Archaeology Review" 3/4:5-9.

Sasson, J. M. 1981. "On Choosing Models for Recreating Israelite PreMonarchic History." Journal for the Study of the Old Testament 21:3-24.

Saussure, F. de. 1966. Course in General Linguistics. Ed. C. Bally and A. Sechehaye with A. Riedlinger. Tr. W. Baskin. New York.

Scholes, R. 1984. Textual Power. New Haven.

Scholes, R. and R. Kellogg. 1966. The Nature of Narrative. New York.

Segal, M. H. 1967. The Pentateuch, Its Composition and Its Authorship, and Other Biblical Studies. Jerusalem.

Selms, A. van. 1977. Review of Abraham in History and Tradition by J. Van Seters. Bibliotheca Orientalis 34:204-5.

Stein, Gertrude. 1982. Blood on the Dining-Room Floor. Berkeley.

Steiner, George. 1975. After Babel. London/Oxford/New York.

Thompson, T. L. 1978. "A New Attempt to Date the Patriarchal Narratives." Journal of the American Oriental Society 98:76-84.

Tigay, J. H. 1975. "An Empirical Basis for the Documentary Hypothesis." Journal of Biblical Literature 94:329-42.

1982. The Evolution of the Gilgamesh Epic. Philadelphia. ed. 1985. Empirical Models for Biblical Criticism. Philadelphia.

Tov, E. 1984/85. "Qériteryônîm lěha arakat girsā’ôt teqsțuāliyyôthahagbälôt šel kếlâlim qěvû́îm." Beth Mikra 30:112-32.

Tsevat, M. 1975. "Common Sense in Old Testament Study." Supplements to Vetus Testamentum 28:217-30.

Van Seters, J. 1975. Abraham in History and Tradition. New Haven.

1978. "Dating the Patriarchal Stories." Biblical Archaeology Review 4/4:6-8.

1983. In Search of History. New Haven.

Wagner, N. E. 1977. "A Response to Professor Rolf Rendtorff." Journal for the Study of the Old Testament 3:20-27.

Winnett, F. V. 1965. "Re-examining the Foundations." Journal of Biblical Literature 84:1-19. 